\title{
FAMÍLIAS DA ELITE RURAL ESTANCIEIRA DO RIO GRANDE DO SUL: MEIOS DE INTERAÇÃO SOCIAL E CULTURAL E ESTRATÉGIAS MATRIMONIAIS E SUCESSORAIS DE REPRODUÇÃO SOCIAL
}

\section{FAMILIES FROM THE RURAL PATRONAGE ELITE IN RIO GRANDE DO SUL: MEANS OF SOCIAL AND CULTURAL INTERACTION, AND MARITAL AND SUCCESSION STRATEGIES OF SOCIAL REPRODUCTION}

\author{
Marcos Botton Piccin*
}

Introdução

Este artigo analisa os principais meios de interação social e cultural e as estratégias matrimoniais e sucessorais de reprodução social da elite, grande proprietária de terra criadora de gado extensivo no Rio Grande do Sul, cujos domínios se convencionou chamar de estâncias, e de estancieiros os seus senhores ${ }^{1}$. São seis as linhagens consideradas de grandes proprietários do município de São Gabriel que realizaram matrimônios ao longo do século XX. Os meios de interação social e cultural analisados se perpetuaram até mais ou menos o final da década de 1980, quando ocorre uma maior unificação do mercado de bens simbólicos. Em outras palavras, busca-se apontar processos da sociabilidade das elites estancieiras que são essenciais para a incorporação da estrutura objetiva do espaço social em esquemas de percepção e afinidades de estilos de vida, ao proporcionar que os matrimônios se deem, preferencial-

\footnotetext{
* Professor dos Programas de Pós-Graduação em Extensão Rural e Pós-Graduação em Ciências Sociais da Universidade Federal de Santa Maria - UFSM - (Santa Maria/RS/Brasil). Doutor em Ciências Sociais pela UNICAMP. E-mail: marcospiccin@gmail.com

1. Este artigo foi apresentado inicialmente para a discussão em uma seção do Groupe de Réflexion sur le Brésil Contemporain, na École des Hautes Études en Sciences Sociales, coordenado por Afrânio Garcia Jr. Tenho muito a agradecer a todos e todas que sugeriram alterações à versão inicial, em especial às contribuições do Afrânio às várias versões deste texto.
} 
mente, entre posições homólogas, constituindo duas faces de uma mesma estratégia de reprodução social (BOURDIEU, 2002a).

Por estratégias de reprodução social entendemos o conjunto das práticas por meio do qual um grupo de indivíduos consegue perpetuar as estruturas e as relações que o constituem. A análise desse processo se dá através dos meios utilizados para se transferir, de uma geração para outra, os recursos que permitam o estabelecimento, exitoso/ou não, dos seus descendentes (BOURDIEU, 1989, 2002a, 2008; BONNAIN; BOUCHARD; GOY, 1992; VIRET, 2008). No que tange aos grupos dominantes, falar em estratégias de reprodução social refere-se às práticas através das quais se busca conservar ou ampliar seus diferenciais de poder em relação aos demais agentes do espaço social.

Dentre as principais estratégias estão as propriamente econômicas; as educacionais; as que visam legitimar a dominação e seu fundamento; as sucessorais, que visam assegurar a transmissão do patrimônio; as estratégias de fecundidade, uma vez que o futuro da linhagem e seu patrimônio depende do número da prole. Um conjunto muito especial dessas estratégias são as de investimento social, orientadas para a instauração e manutenção de relações sociais mobilizáveis e utilizáveis a curto ou a longo prazo, em que as estratégias matrimoniais são um caso particular, pois tendem a assegurar as posições dominantes da família pelas alianças com outra(s) família(s) mais ou menos equivalente(s), sob todos os aspectos socialmente pertinentes (BOURDIEU, 1989).

Essa equivalência é celebrada nos meios de interação social e cultural, como clubes, eventos esportivos, associações literárias, bailes, teatros e outros que constituem uma maneira específica de transmitir o status e os papéis sociais. São momentos muito especiais para uma certa comunhão de gostos, valores, práticas e estilos de vida que possibilitará, por um processo de afinidades eletivas, que a homologia do matrimônio tenha a força de liberdade. Este processo desencoraja relações sociais assimétricas. Impele as relações consideradas adequadas. Quer dizer, há um princípio de reprodução dos esquemas de percepção, de apreciação e de ação dos agentes, que não somente acompanha tais estratégias, como as orienta. Esses esquemas de percepção e apreciação são internalizados na forma de habitus ao longo dos processos de socialização dos indivíduos. Ou seja, um sistema de disposições duráveis que orienta as percepções dos indivíduos: um conjunto de domínios e códigos que formam um determinado senso prático que orienta as formas de agir, reagir, pensar e desejar (BOURDIEU, 1989, 2002a, 2008). Mesmo que muito diferentes, as práticas se organizam objetivamente de maneira a buscar a reprodução da estrutura do espaço social, nas necessidades imanentes na posição que se trata de reproduzir e no habitus que lhe corresponde.

Durante o período analisado, essa elite estancieira vivenciava processos de ascensão tanto política quanto econômica, ao contrário de seus congêneres senhores de engenho do Nordeste (GARCIA JUNIOR, 1989, 2007) e barões do café do Sudeste (STOLCKE, 1986). A Revolução de 1930 catapultou os seus descendentes aos primeiros postos de mando nacional, tanto antes quanto depois do golpe de 1964, até o processo de redemocratização (PICCIN, 2015). No plano econômico, a substituição das charqueadas por uma rede de frigoríficos, cujo preço do gado era controlado pelos próprios produtores, em uma sociedade que se urbanizava e cujos preços foram crescen- 
tes durante todo o período, os transformou de produtores subsidiários das principais lavouras de exportação - cana de açúcar e café, onde o charque alimentava as classes trabalhadoras dessas plantações -, em produtores de artigos de luxo, porque a carne frigorificada passou a ser consumida pelas classes ricas e remediadas (PICCIN, 2014). É nesse contexto, em que a realidade parece atestar o êxito das estratégias de reprodução social acionadas pelos estancieiros, que a análise deste artigo se desenrola.

Nesta análise, o sentido dado à ideia de "linhagem" é como grupo de filiação extenso e segmentado interiormente, onde as relações de pertencimento são calculadas em termos genealógicos precisos, cujo parentesco é bilateral (GOODY, 1985). A herança do patrimônio é transmitida igualitariamente entre filhos(as) de uma mesma família, entendida como grupo doméstico formado pelo casal e filhos(as) legítimos(as). Não se trata, portanto, de uma análise da parentela (LEWIN, 1993) ou de uma concepção de família alargada (FREYRE, 1987), por mais que os dados de campo também apontem para esse diálogo (PICCIN, 2012), mas de investigar um conjunto de relações específicas às genealogias destes senhores de terras.

Este artigo está dividido em quatro seções, além desta introdução e a conclusão. $\mathrm{Na}$ primeira seção, se realiza um mapeamento da bibliografia especializada e se argumenta sobre a escassez de estudos nessa área. Na segunda seção, se analisam os meios de interação social e cultural dessa elite estancieira, que almeja o cosmopolitismo em um espaço social de ampla distinção social. Na terceira seção, se analisam as estratégias matrimoniais propriamente ditas, cuja homologia de posições é central para compreendê-las. Na quarta seção, são as estratégias de transmissão do patrimônio produtivo e herança que são analisadas.

Esta pesquisa foi realizada entre 2009 e 2011, com observação direta no município de São Gabriel para a produção dos dados etnográficos. A pesquisa em profundidade das seis linhagens de estancieiros envolveu a análise de 99 matrimônios e 233 indivíduos, além da entrevista com 16 estancieiros e/ou casal de estancieiros com posses fundiárias acima de um mil hectares, e uma pesquisa minuciosa em documentos presentes na biblioteca do município e na Superintendência do Instituto de Colonização e Reforma Agrária do Estado, além dos documentos pessoais das próprias famílias. 0 número de linhagens foi definido a partir do que os entrevistados entendiam ser as "mais importantes" na história do município, tendo-se acesso às suas redes de interconhecimento, além do critério das variações nos pertencimentos políticos e oposições tradicionais.

\section{A pobreza de pesquisas sobre os ricos... do rural}

Pinçon-Charlot e Pinçon (2018) argumentam que há uma "pobreza das pesquisas urbanas sobre os ricos" quando comparadas àquelas que analisam os grupos subordinados. Se é assim no caso da análise da alta burguesia, processo semelhante, mas com um fosso ainda maior, o mesmo se dá com os estudos que analisam os ricos do rural. Não que haja necessariamente uma separação entre os ricos de um espaço social e os de outro, pois muitas vezes se tratam das mesmas pessoas, quer reproduzam no urbano suas posições de dominante no espaço rural, quer reproduzam no rural suas posições de dominante no urbano. Para analisar as classes mais bem situadas 
no espaço social, não se pode fragmentar a sociologia como "urbana" ou "rural", pois essas pessoas circulam, consomem bens culturais diversos, não estando restritos a apenas um dos espaços. Sobretudo, em se tratando de municípios não metropolitanos do Brasil, na maior parte das vezes, essa é a máxima. Mesmo os ricos do urbano, muitos deles, possuem no rural locais para lazer e/ ou exploração econômica. 0 caso recente de aquisições de terras via mercado financeiro é dos casos possíveis que modificam as relações entre classes e grupos, sejam rurais ou urbanos (SAUER; LEITE, 2012.). De todo modo, as análises que privilegiam as relações sociais tecidas pelos dominantes que se apresentam enquanto tal no espaço rural são muito poucas, e ainda mais raras são as investigações em perspectiva comparada internacional (MOORE JUNIOR, 1983).

A bibliografia internacional que analisa as práticas e o comportamento econômico dos grupos dominantes possui como objeto de estudo as linhagens e grupos de industriais, empresários, banqueiros e executivos, mas não as elites econômicas no rural (ZALIO, 2004; SWEDBERG, 2004; STEINER, 2006; PINÇON; PINÇON-CHARLOT, 2006, 2007; OFFERLÉ, 2009). Quanto ao estudo dos setores dominantes, vale um destaque para as pesquisas empreendidas por Bourdieu desde a década de 1970 (BOURDIEU; SAINT MARTIN, 1978; BOURDIEU, 2008) e por seu grupo, reunidos no atual Centre Européen de Sociologie et Sciences Politique (DENORD; LAGNEAU-YMONET, 2016). A bibliografia que analisa esses grupos dominantes procura mostrar, ao mesmo tempo, as diferenças, mas também o que os constitui enquanto classe social num espaço de inter-reconhecimento e reconhecimento, em que a "nobreza" afortunada coexiste com famílias burguesas, de linhagens de famílias antigas e de linhagens de recente ascensão. Mostra ainda como esses grupos se moldam e se guetizam nos espaços urbanos, das trajetórias individuais e dos capitais acumulados, cuja riqueza é multiforme, indo dos capitais econômicos, aos sociais, culturais e simbólicos.

No Brasil, a bibliografia que analisa os grandes proprietários de terra tem colocado questões que são fundamentais para se compreender como agem esses grupos, especialmente no que se refere à representação e mobilização política (HEINZ, 1996; GRILL, 2003; BRUNO, 2012; DA ROS, 2012; CANEDO, 2002; COSTA, 2019), as trajetórias de grupos específicos (GRIJÓ, 1998; SEIDL, 1999), o trabalho de construção simbólica que esses grupos fazem de si próprios (HEREDIA; PALMEIRA; LEITE, 2010), os investimentos econômicos em terras (BÜHLER; GUIBERT; OLIVEIRA, 2016) ou mesmo o uso que fazem dos financiamentos agrícolas como forma de acumulação primitiva (CAMARGO, 2009; RAMOS, 2011). Os estudos que analisam as estratégias de reprodução das famílias focam, em sua grande parte, na reprodução do poder político da família (SANTOS, 2017; ALVES, 2017; MONTEIRO; FERREIRA, 2017), mas com pouca atenção para outras estratégias de reprodução social. São poucos os trabalhos em que as estratégias matrimoniais de grandes proprietários se constituem como objeto de estudo, com destaque para Lewin (1993), e, além disso, quase todos com atenção ao século XIX e anteriores (PEDROZA, 2010; ALVES, 2017; MARTINS, 2017).

Este artigo busca contribuir com a análise de como se perenizam os grandes proprietários de terras no Brasil, a partir da investigação dos principais meios de interação social e cultural e de suas estratégias matrimoniais e sucessorais. A análise dos 
círculos de sociabilidade e estilos de vida permite investigar as origens aristocráticas dessa elite rural, em específico, em que praticamente inexistem estudos sobre os estancieiros, como se veem e em qual lugar se veem, além das origens do que é o oposto no espaço social, ou ainda, de nossa espantosa desigualdade social enquanto país.

\section{Sobre a socialização das elites estanciei- ras}

A entrevista realizada a campo com uma senhora estancieira de 77 anos foi reveladora do sentido dos limites que o espaço social impunha para se realizar o que se considerava um bom matrimônio. Quando ela e suas irmãs buscavam informar ao pai sobre seus pretendentes, ele os classificava como aqueles que "tinham um pé na senzala", os que "não conseguiriam nem mesmo garantir a própria comida" e os que “eram de sociedade”. A classificação é a representação do espaço social estancieiro em que as classes trabalhadoras pobres e recém-saídas da escravidão são as primeiras a se manter distância. As classes médias também estavam excluídas pela ausência de propriedades econômicas ou simbólicas como forma de garantir a reprodução dos estilos de vida de elite; não bastava "garantir a própria comida”, mas as condições para se assegurar uma distância da necessidade pelo envolvimento em atividades culturais diversas, e não apenas aquelas ligadas ao mundo da produção na terra. A distância da necessidade e a expressão de um habitus desinteressado diante das questões mundanas constitui-se como a principal distinção social que acaba por ser acumulado como capital simbólico por aqueles que "eram de sociedade". Exercitar e comunicar esse habitus desinteressado era uma das con- sequências dos muitos meios de interação cultural e social estimulados por essa elite grande proprietária de terra, como feiras de exposições de gado, bailes, atividades literárias, campeonatos diversos de polo e tênis, que cimentavam um determinado cosmo social, ampliavam as possibilidades de constituição de casamentos homólogos e constituíam um senso de orientação social.

Nesse espaço social, as hierarquias estão diretamente ligadas ao tamanho das posses de terra ou de um título capaz de garantir aumento de capital simbólico, ou seja, de atestar a legitimidade social de elite às famílias. Na economia estancieira criatória extensiva, quanto maior a produtividade do trabalho por área explorada, ou seja, quanto maior a extensão de terras sob o cuidado de cada trabalhador, maior o estoque de gado à disposição do estancieiro para manter ou aumentar os padrões de consumo de sua família. Da mesma forma, maiores são as possibilidades de dar uso diferenciado às terras e aumentar as receitas, de modo que um clube ou associação cultural pode ser formada justamente em momentos de maior diminuição dos preços de bovinos, conferindo relevo ao restrito grupo de fundadores.

Em se tratando das posições dominantes no espaço social estancieiro, há um estilo de vida a ser reproduzido, cuja distinção se dá pela possibilidade de utilizar o tempo principalmente com situações que não estejam ligadas ao econômico. Viver do próprio trabalho, ou do trabalho de outrem nas questões da estância, está na base de uma distinção social que divide o espaço social e atribui aos que vivem do próprio trabalho o rótulo de gaúchos. As designações nativas dizem muito também sobre a posição social que as classes ocupam neste espaço social. Gaúcho designa aquele indivíduo, ou os integrantes de uma família, que são obrigados 
a trabalhar em suas terras ou em propriedade alheia, sob as ordens de outra pessoa, para prover a própria subsistência; são, de modo geral, as classes médias proprietárias. Uma variação é o termo gauchinho que designa especificamente os peões de estância, mas que pode ser utilizado em diferentes contextos sociais com significado pejorativo. 0 termo que designa os peões é no diminutivo e expressa a posição mais subordinada no espaço social; são as classes trabalhadoras com pouca terra ou nenhum outro recurso para sobreviver que não a venda da sua própria força de trabalho.

Um senhor de terras, proprietário de estância(s), pode trabalhar diretamente em suas posses dando ordens aos seus subordinados, mas a qualificação de gaúcho ou gauchinho é restrita aos subordinados. 0 uso da palavra gaúcho pela elite estancieira como categoria política de nós se dá em jogos sociais externos à economia estancieira, como nas lutas reivindicativas ao Governo Federal e em enfrentamentos com outras elites nacionais. Nesses momentos é que os estancieiros "conjuram temerosamente a ajuda dos espíritos do passado, tomam emprestados os seus nomes, as suas palavras de ordem, o seu figurino (...)" (MARX, 2011, p. 26) para lhes dar força simbólica em defesa de seus interesses, mas não é essa a representação que constroem deles próprios no espaço de relações estancieiro.

A possibilidade de uso do tempo com as questões do espírito - pintura, música, poesia, esportes, política -, é designativa de toda a distinção social. Em 1940, o município de São Gabriel, então com 35.849 habitantes, tinha oito associações literárias e artísticas, oito entidades esportivas, dois teatros e dois clubes sociais - o Caixeiral e o Comercial. Somente naquele ano foram realizados 53 torneios de tênis e polo no município e região da Campanha. Entre os clubes sociais, o Caixeiral é o mais antigo; fundado em 1895, reunia grandes proprietários de distintas facções políticas, comerciantes e funcionários públicos. 0 Clube Comercial nasce em 1914 como "Casino Gabrielense”, com apenas 54 sócios, depois muda de nome em 1931 (SILVA, 1963). Em 1936, a imprensa local rebatizou esse clube para "Aristocrata Clube Comercial de São Gabriel” ao noticiar com grande entusiasmo a fundação de um "Clube dos Aristocratas” em Nova York ${ }^{3}$. Uma das reportagens dedicadas a celebrar tal distinção parabenizava "a sociedade" municipal por fazer parte de um "seleto grupo com a existência do clube" ${ }^{4}$, o que fala muito sobre como se representava essa elite rural.

A associação nesse clube era restrita aos grandes proprietários rurais, altos funcionários do Estado e militares cujas patentes fossem superiores ou igual às de tenente. Em 1940, o Aristocrata Clube Comercial inaugurou uma ampla sede no centro da cidade, de frente para a praça e ao lado do prédio da igreja católica local. Dentre os bailes organizados pela elite local, o mais importante era o Baile das Nações, no qual as mulheres vestiam a roupa típica de algum país do globo terrestre e os homens vestiam ternos de gala, além dos bailes de máscaras e dos que ocorriam durante as exposições de gado. Nos carnavais, no referido clube ou na rua da praça central do município, as canções que faziam suces-

3. Ver as edições do jornal 0 Imparcial de 18 e 31 de outubro de 1936.

4. Jornal 0 Imparcial, 31 de outubro de 1936, p.10. 
so na capital do país animavam as festas. Os trajes para os bailes eram encomendados do Rio de Janeiro, se a família tivesse condições de pagar tal preço para garantir a distinção, ou encomendado sob medida de Bagé, município vizinho. Ademais, em 1940, São Gabriel apresentava dois conservatórios de música, sendo um particular e outro mantido pela prefeitura, três entidades beneficentes e duas lojas maçônicas.
Em 1941, foi fundado o Aéreo Clube e a aquisição de aeronaves particulares pelos maiores estancieiros passou a fazer parte de seus estilos de vida a partir de então (PIMENTEL, 1941; SILVA, 1963). As imagens, a seguir, tiradas de álbuns das famílias estancieiras entrevistadas, traduzem alguns desses momentos:

Um dos eventos mais importantes de co-

Figura 1: Baile de Máscaras em 1975.

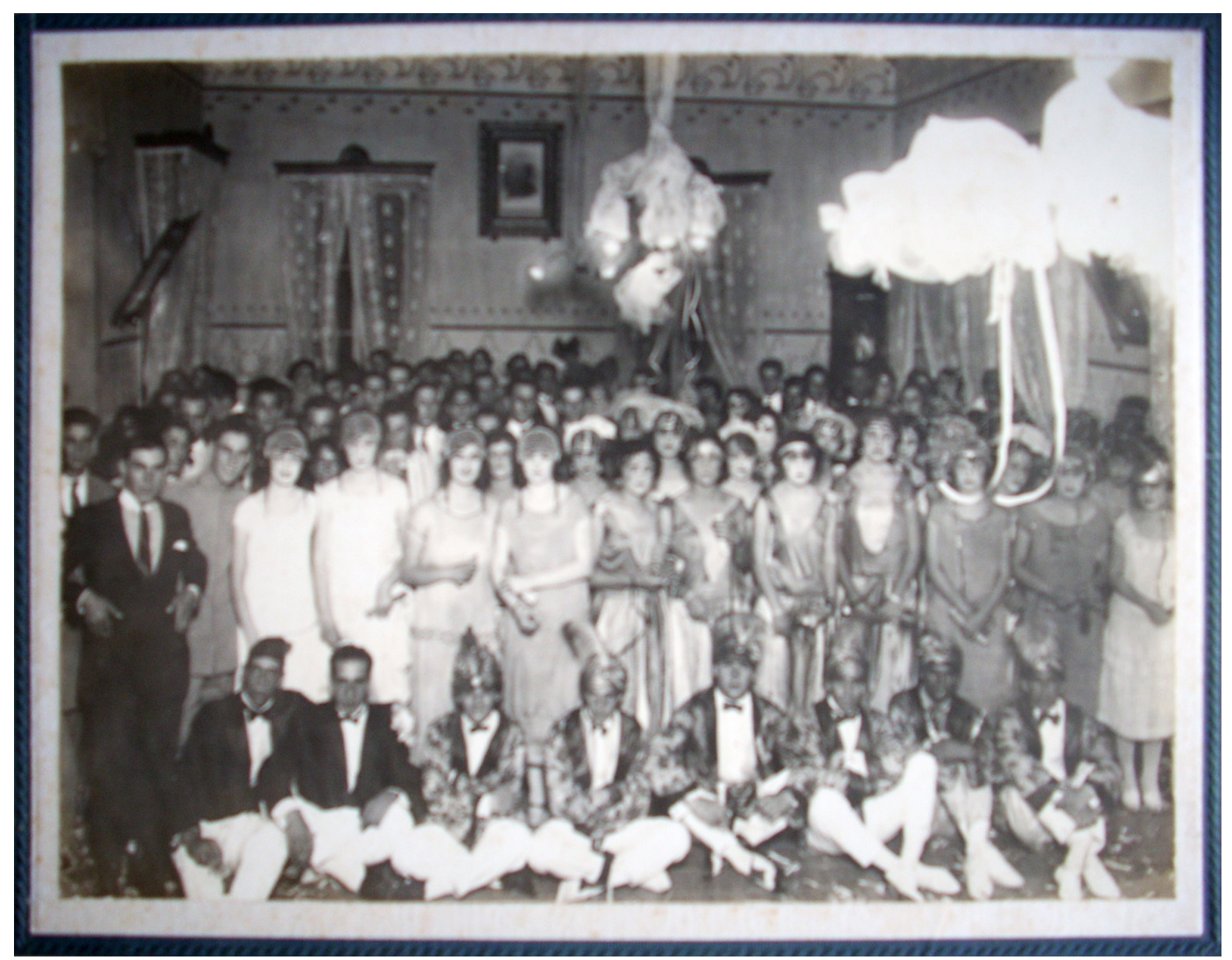


Figura 2: Carnaval em 1960.

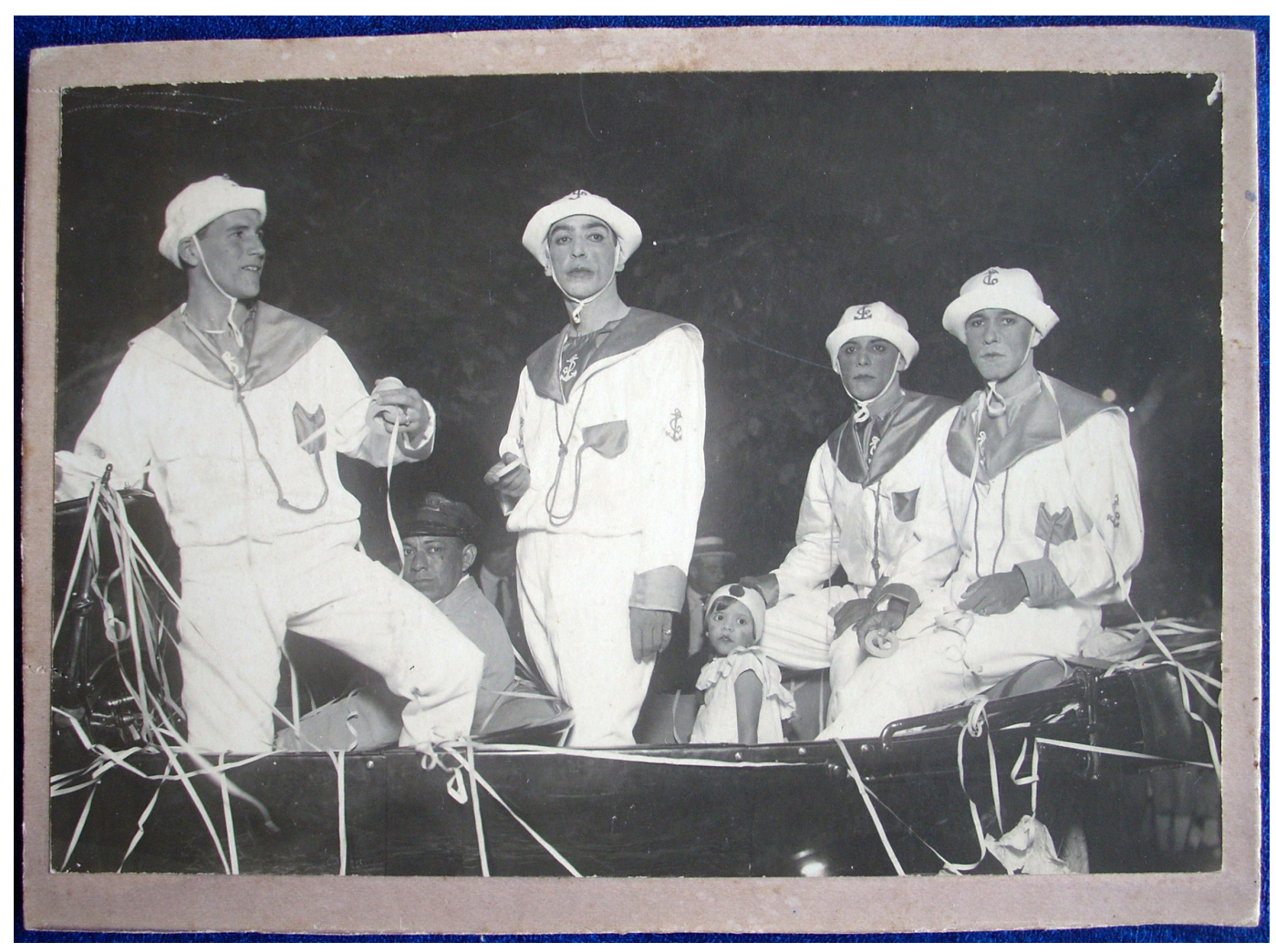


Figura 3: A distinção dos estilos de vida com a presença de aviões nas exposições de gado em 1975. Destaque para um garçon que serve o público na imagem do canto inferior esquerdo.

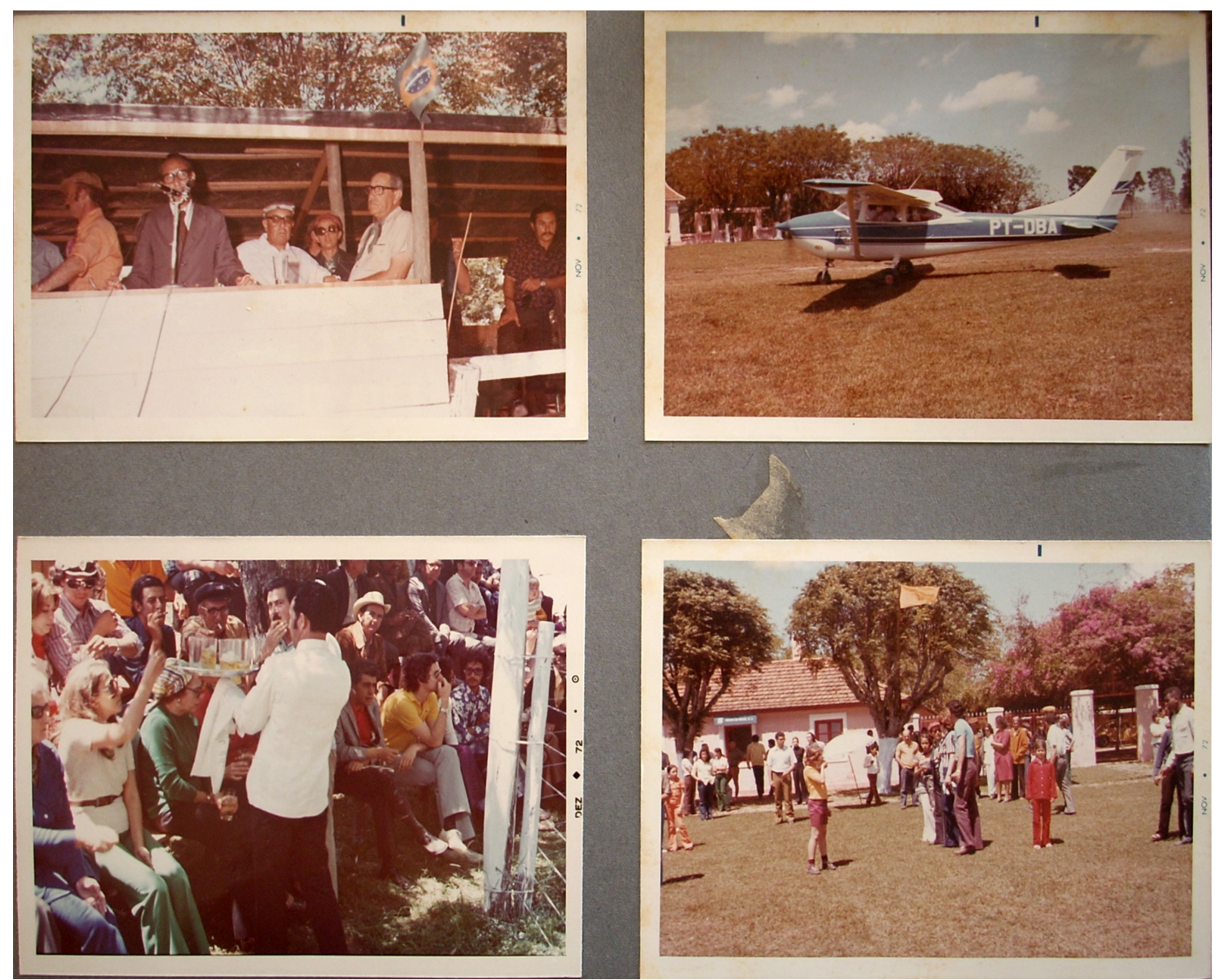


Figura 4: A distinção dos estilos de vida com a presença de aviões nas exposições de gado em 1975. Destaque para a presença de um escritório do Banco do Brasil na imagem inferior esquerda.

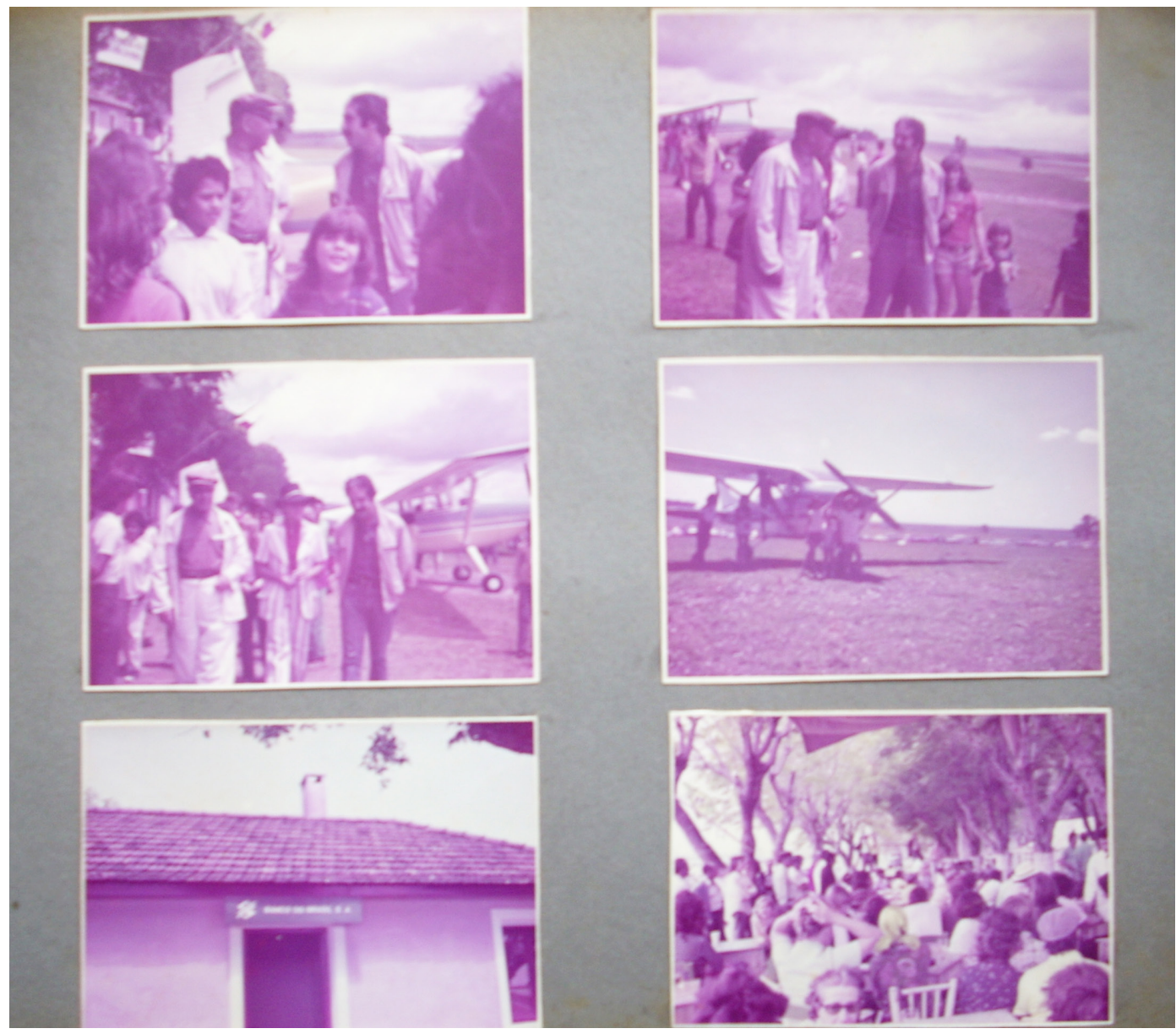


memoração da distinção social era a Feira de Exposições Rurais. As primeiras Exposições foram realizadas em 1920 e 1921, depois só reativadas a partir de 1937, com edições anuais, ininterruptas, até o final da década de 1980. Estas Exposições tinham a duração de três dias, em que os principais pecuaristas mostravam o que de melhor criavam em suas estâncias. Mas as principais situações de comemoração das distinções sociais ocorriam à noite, nas festas que realizavam. Pelo menos a partir da década de 1960, para cada dia da Exposição seguia um tipo diferente de baile: baile de gala, baile à fantasia e baile do tipo esporte fino ${ }^{5}$. Como nas outras ocasiões, também para estas os vestidos ou eram feitos sob medida por costureiras de Bagé ou eram encomendados diretamente do Rio de Janeiro.

Em 1941 havia três agências bancárias, uma do Bergs - banco que, posteriormente, foi renomeado como Banrisul -, e outras duas do Banco Nacional do Comércio e Banco da Província. Em 1963, outras quatro instituições bancárias também instalaram filiais no município: o Banco do Brasil, a Caixa Econômica Federal, o Banco Agrícola Mercantil e o Banco Militar Brasileiro. Desde a década de 1940, duas companhias aéreas, a Varig e a Savag, realizavam voos semanais para cidades da fronteira, capital do estado, São Paulo e Rio de Janeiro ${ }^{6}$. Em 1970, foi construída a BR 290, que ligou Uruguaiana, Alegrete e São Gabriel a Porto Alegre, diminuindo o tempo de desloca- mento por terra para a capital do estado. $\mathrm{Na}$ mesma década, o transporte ferroviário foi desativado.

Por volta de 1960, havia dois teatros com capacidade para 1.100 lugares, e dois cinemas com capacidade para 1.500 espectadores (PIMENTEL, 1941; SILVA, 1963). Nas décadas de 1970 e 1980, vários cantores nacionais da MPB, como Roberto Carlos, fizeram shows na cidade ${ }^{7}$. Em 1959, para comemorar o centenário da cidade, a prefeitura municipal publicou um livro com 69 poemas e prosas de 37 autores do município, depois de um concurso realizado. A fervilhante vida cultural levou à prefeitura a intitular o município como a "Atenas Riograndense" (PREFEITURA MUNICIPAL DE SÃO GABRIEL, 1959). Isso tudo quer dizer que essa elite rural buscava o cosmopolitismo, no sentido de consumir os bens culturais, como música, literatura e idiomas de outros países e dos que estavam em pleno auge em na capital do país. Trata-se da celebração do habitus desinteressado e da distinção social desse grupo em poder se manter distante da necessidade. É interessante a autoimagem que a elite rural construía de si própria: a cidade de Platão e Aristóteles, o berço da civilização ocidental e da democracia, centro irradiador cultural e filosófico, era a referência da elite rural estancieira.

Como na atividade estancieira criatória extensiva não é necessária a presença ininterrupta do estancieiro no comando das

5. As mulheres que entrevistei não souberam me confirmar a ordem dos bailes, mas este era um dos primeiros aspectos por elas lembrado quando passavam a relatar suas experiências nas décadas de 1970 e 1980.

6. Ver Jornal O Imparcial, edições de 1949.

7. As fotografias dos diversos shows podem ser vistas nos arquivos pessoais das famílias entrevistas; também podem ser vistas no Pub “Tim Bar”, localizado na rua Dr. Mauricio, entre as ruas Barão de São Gabriel e Cel. Sezefredo. 
ordens aos peões, por ser realizado pelo capataz, tornava-se comum aos grandes proprietários passar uma temporada, especialmente o período do inverno, em Porto Alegre ou Rio de Janeiro, retornando para a estância no período do verão. $0 u$, então, aumentar sua presença nos assuntos da política da cidade, dos clubes, da vida intelectual ou dos esportes. A posse de casa na cidade de São Gabriel, ou apartamento em Porto Alegre ou no Rio de Janeiro permitia que a presença da família do estancieiro na estância ocorresse apenas nas férias escolares. Das seis linhagens de estancieiros pesquisadas, todas as famílias entrevistadas relataram possuir ou já terem possuído moradia em Porto Alegre ou Rio de Janeiro, lá permanecendo parte do ano. Medeiros (1969) registra situações em que os capatazes assumiam todas as funções de mando na estância, inclusive a compra e venda de animais, depois da autorização dos patrões.

A citação de situações, entidades e estilos ganha ordenação no fato de que são traços distintivos que agem como sistemas de diferenças e distâncias diferenciais entre as distintas posições no espaço social. Essas posições exprimem as mais fundamentais diferenças nesse universo social, que possui sua base na posse da propriedade da terra, e se entrelaça com o acúmulo de capital cultural, capital social e capital simbólico. A distinção encontra-se objetivamente inscrita em cada baile, no vestido importado ou feito sob medida, nas aulas de música ou associação literária, nas viagens de avião, na atividade política, entre outras, e está internalizada nos corpos das pessoas como sistema simbólico que classifica e legitima as divisões no mundo social. Mas esse estilo de vida e os gostos recíprocos como condição situada em determinada posição no espaço social, numa conjuntura de va- lorização das condições de troca em benefício do estancieiro, tomam ainda mais relevo quando analisado em relação a outras posições no espaço social, tendo por base a distribuição da propriedade fundiária.

Para efeito metodológico, a entrevista realizada com dona Inês (concedida em 09/06/2011) sobre a história de sua família é reveladora das homologias entre posição social e estilos de vida, além das afınidades eletivas do espaço social em estudo no tocante às classes médias e pequenas proprietárias. A entrevista com Dona Inês ocorreu no interior do município, no antigo Rincão dos Bandeiras, onde ela e seu marido, já falecido, tiveram um pequeno comércio, hoje praticamente desativado. Dona Inês nasceu em fevereiro de 1934, a oitava de um total de doze irmãos, seis homens e seis mulheres, na localidade chamada de Rincão de Santa Catarina, segundo suas palavras, "na beira de um banhado", ou seja, de áreas alagadas, em São Gabriel. A família tinha "um campinho" de "quatro quadras de campo", equivalente a 348 ha. Ali todos os filhos trabalhavam, "sempre na terra", criavam gado e plantavam milho para realizar as trocas monetárias necessárias para a família adquirir a "manutenção" para a casa: tecidos, açúcar, sal, etc. Os que mais estudaram, o fizeram até a $5^{\circ}$ série em uma escola da região. Assim que os irmãos homens foram casando, instalaram suas novas casas na propriedade paterna. 0 milho para ser vendido na cidade era enviado por carroça de boi, depois de retirada a parte para a alimentação dos animais e para se fazer farinha para consumo da família. Até por volta da década de 1960, o trigo e o arroz eram produzidos somente para o consumo da casa, assim como a plantação de mandioca, da qual se fazia farinha e polvilho. Também criavam galinhas e suínos para o 
consumo da casa. Os bovinos serviam para se fazer as "juntas de boi" que puxavam o arado e os carros de boi, faziam queijo, uma parte dos animais era destinada para venda e, em cada entrada de inverno, carneavam-se duas reses para fazer charque. Certos comerciantes realizavam excursões no interior do município com mercadorias sobre burros, em jacás, dos quais sua família comprava "as fazendas e panos", sendo as roupas costuradas pelas mulheres. Quando o trigo e o arroz começaram a "ter valor”, alguns de seus irmãos expandiram as plantações na propriedade do pai, "tudo com a ajuda das juntas de boi” e depois "arrendaram mais campos” para plantar. Seu marido, com quem casou em 1957, também havia arrendado um "pedacinho" para plantar milho nas terras de um estancieiro, mas foi com a abertura de "uma venda" no Rincão dos Bandeiras, de onde o marido vinha, que o casal passou a ganhar a vida. De acordo com Dona Inês, em cada Rincão se faziam bailes com alguma frequência. Mas não era qualquer um que podia participar, pois "as famílias eram classificadas e se tiravam os negros, os bêbados e os que tivessem um vício ruim"; os demais recebiam o convite se fossem conhecidos. Os moços se vestiam com bombachas, botas e lenço: "todos se vestiam assim". Outra atividade que se fazia nos finais de semana eram as "carreiras de cavalo", e havia uma "cancha de carreira" na propriedade de seu pai - as “carreiras" são competições entre cavaleiros para ver qual cavalo é o mais veloz.

Pelo lado estancieiro, a objetivação mesmo que resumida das trajetórias de Marçal de Assis Brasil e sua esposa, Isabel da Jornada Dorneles, é interessante pelo que depõe quanto aos estilos de vida e ligações familiares. Marçal nascera em 1904, se alfabetizou na estância de seu pai, fez colégio militar em Porto Alegre, bacharelou-se em direito na UFRGS, e depois de acompanhar seus tios como interventores no Governo de Santa Catarina devido à Revolução de 1930, trabalhou no Ministério da Guerra na capital federal entre 1940 e 1941, tendo falecido em 1953. Marçal é descrito pela família como atleta e ginasta de barra e solo, exímio tenista e cavaleiro, além de poliglota. Isabel era irmã de um dos melhores amigos de Marçal na faculdade de direito, Oneron Dorneles, primo materno de Getúlio Vargas e um dos dirigentes do Partido Comunista no estado, tendo sido candidato a deputado estadual nas eleições de 1947. Isabel, que nasceu em 1907, atual município de Santiago, é descrita como praticante de esportes, poliglota e versada em história e literatura; morreu no ano de 2000, em São Gabriel.

Estes dois exemplos, ou situações - relativos ao universo de sociabilidade estancieiro e ao universo de sociabilidade das demais classes subordinadas -, significam as localizações dos indivíduos no espaço social, determinadas, fundamentalmente, pelo capital fundiário de que dispõem. Pode-se dizer que representam um determinado estado do volume de distintos capitais acumulados e que conformam as diferentes homologias em cada posição social. Todo o sistema de posições, neste caso, poderia ser resumido pelos esportes praticados: tênis e polo, no primeiro caso, e "carreira de cavalos”, no segundo caso. Ou então pelos clubes e estilos de bailes nos quais as pessoas participam. Assim, não é de se estranhar o fato de que das 16 entrevistas realizadas com estancieiros, todos proprietários acima de 600 hectares, apenas um deles tenha respondido que participava de um dos oito Centros de Tradições Gaúchas (CTG’s) do município. As respostas dos demais tra- 
taram de afirmar categoricamente que não participavam de nenhum dos CTG's, e se reportavam aos indivíduos que frequentavam como "eles", em oposição a “nós". Os trajes e os bailes dos CTG's ainda hoje reproduzem o estilo descrito por Dona Inês. Portanto, estamos longe de representar a elite estancieira como vestida em bombachas, botas e lenço, mas sim muito mais próximo do fraque, do smoking e do terno e gravata. As entidades mais citadas nas entrevistas foram o Clube Comercial, hoje em franco declínio, Rotary Club e entidades assistenciais como a Liga das Mulheres de Combate ao Câncer. São trajetórias, disposições sociais e habitus ajustados a posições definidas relacionalmente na estrutura deste espaço de relações objetivas que traduz as relações de poder que se encontram no princípio das distribuições dos diferentes recursos valorizados. Mais precisamente, trata-se de um sistema de relações que exprime um estado de relações de força entre os agentes, grupos e classes de agentes que são expressos pelos gostos e disposições ajustadas em cada posição.

\section{Estratégias matrimoniais propriamente ditas}

As estratégias mais propriamente econômicas, de investimento escolar ou de relações sociais são indissociáveis daquelas que visam a assegurar a reprodução da família e, sobretudo, sua integração. As estratégias matrimoniais compõem o conjunto das estratégias de reprodução dos integrantes do grupo familiar e constituem-se como uma das principais condições para a perpetuação do poder material e simbólico das linhagens. 0 conjunto das estratégias de reprodução encontra seu princípio de reprodução na necessidade imanente da posição que se trata de reproduzir. Em outras palavras, não somente nos estilos de vida, mas quanto aos princípios de visão e divisão, que são ao mesmo tempo individuais e coletivos, porque constituintes de um grupo que se reconhece entre iguais e que fundamenta o consenso sobre o mundo social. A família e as relações matrimoniais exitosas de seus integrantes possuem um papel determinante na manutenção da ordem social, na reprodução, não apenas biológica, mas social. Quer dizer, na reprodução da estrutura do espaço social e das relações sociais (BOURDIEU, 1989, p. 386427; 1996, p. 124-135).

A família é um dos lugares por excelência de acumulação do capital sob seus diferentes tipos (econômico, social, cultural, simbólico) e da transmissão desses capitais ao longo das gerações. Ela não somente resguarda sua unidade pela e para a transmissão, como se torna o princípio das estratégias de reprodução (BOURDIEU; SAINT MARTIN, 1978; BOURDIEU, 1989). Nas famílias que possuem como um de seus principais capitais o econômico, seja em forma de propriedade de terras ou de empresas, as demais estratégias que visam assegurar a reprodução do grupo tendem a se subordinar às estratégias especificamente econômicas visando garantir a reprodução do capital econômico. Nesses casos, o rigorismo em matéria de educação, o horror ao mau-casamento, a exaltação dos valores da família, as estratégias sucessorais do patrimônio e aquelas ligadas aos casamentos endo ou exogâmicos à família, mas com relativa homologia das posições, cumprem aquele mesmo objetivo. Bourdieu (2002b) demonstrou como no campesinato béarnais as estratégias matrimoniais dependiam das estratégias de fecundidade da família, das estratégias educativas - cujo êxito das filhas e dos filhos mais novos era 
condição para que não herdassem parcelas da propriedade -, da existência do celibato e das estratégias propriamente econômicas visando entre outras coisas a manutenção ou o aumento do capital de terras. A não observância dessas práticas para manter indiviso o capital fundiário poderia impor pesados sacrifícios para reestabelecer a posição material e simbólica do grupo, com vistas a compensar as saídas de patrimônio com um mau-casamento de integrantes da família.

No caso das elites agrárias estancieiras, a prática da herança em partes relativamente iguais do patrimônio fundiário dos pais entre os integrantes da fratria, além da fraca presença de casamentos endogâmicos à família, só podem ter reforçado as práticas de manutenção da homologia de posições, como será observado adiante. Antes, analisemos suas estratégias de casamento, que podem ser visualizadas na Tabela 1 abaixo, totalizando 99 uniões matrimoniais das seis linhagens estudadas. 


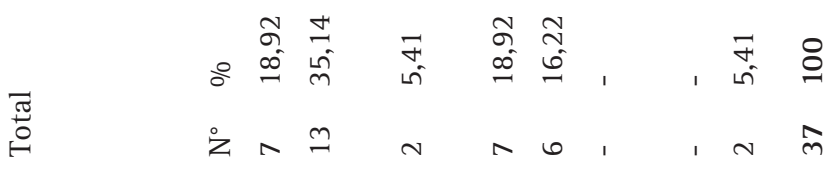

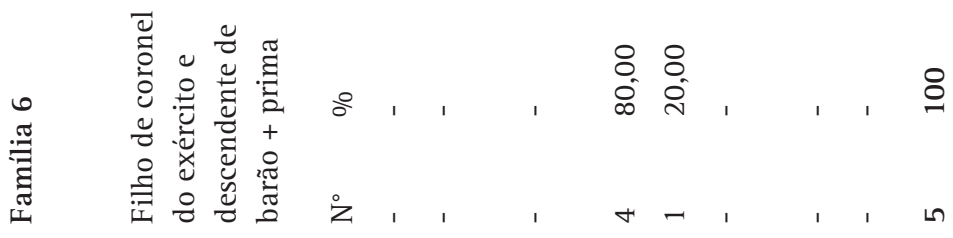

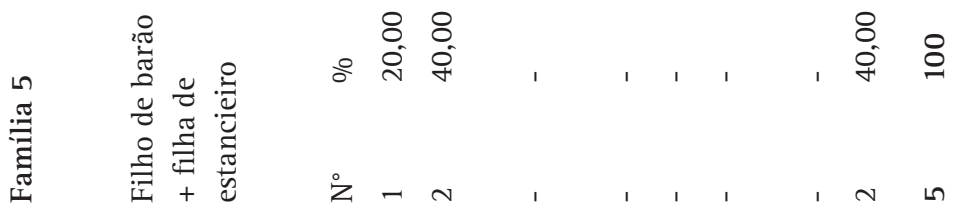

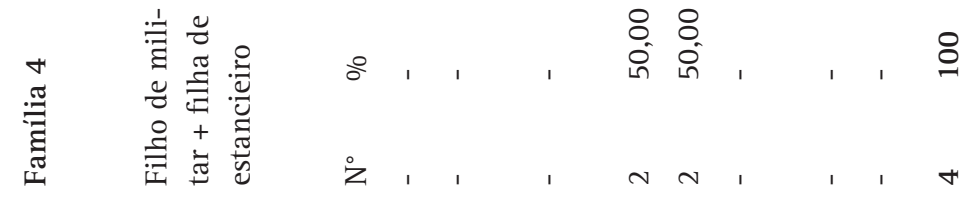

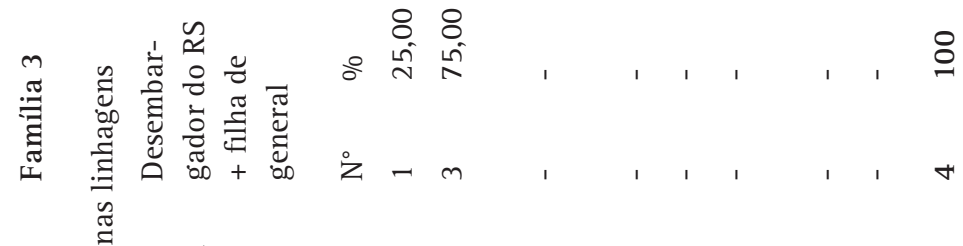

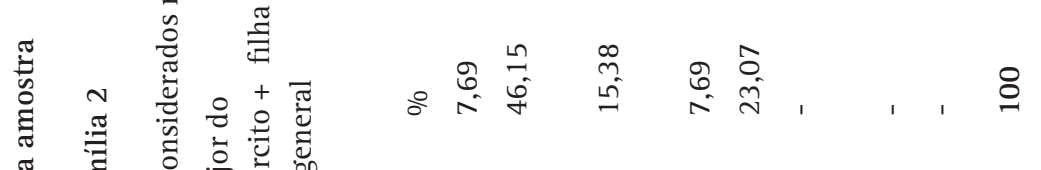




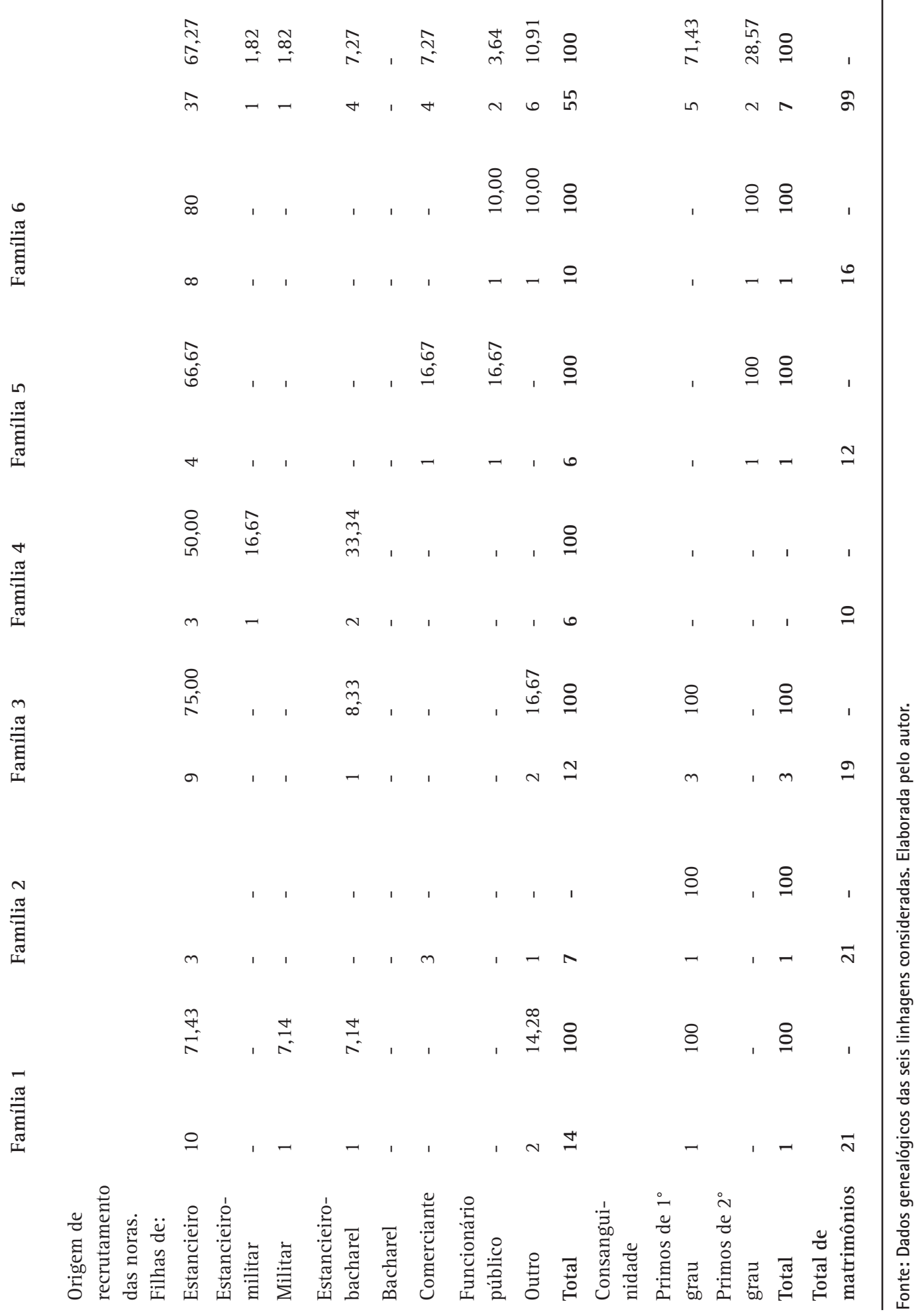


Deve-se observar que, de forma geral, as origens de recrutamento dos cônjuges seguem uma dinâmica semelhante à efetuada pelos iniciadores das linhagens consideradas. A origem e recrutamento dos "genros" à família está concentrada, sobretudo, entre filhos de grandes proprietários fundiários que se tornam estancieiros, o que representa 59,46\% - somando-se as categorias de "estancieiro", "estancieiro-militar" e "estancieiro-bacharel” -, do total dos genros, sendo que 35,4\% deles não acumulam nenhum tipo de título escolar ou militar. Entre os demais, 18,92\% dos genros possuem somente um título militar, cujas patentes são de oficiais; $16,22 \%$ possuem somente um título de bacharel; 5,41\% deles possuem outras origens, considerando-se que tais origens não são nem "comerciante" e nem "funcionário público". Pode-se observar que a maioria do recrutamento dos genros se dá entre a origem estancieira e as possíveis combinações com outros títulos, além de militar-oficial e bacharéis. Somente duas uniões matrimoniais de um total de 37 ocorreram fora desse esquema, respectivos à “família 5", o que, talvez, pudessem ser compreendidos como casamentos não exitosos.

Quanto ao recrutamento das noras, a concentração é ainda maior na categoria de filhas de grandes proprietários fundiários, representado 76,36\% - somando-se as categorias de "filha de estancieiro", "filha estancieiro-militar" e "filha de estancieiro-bacharel"-, do total das noras. Apenas $1,82 \%$ delas são "filhas de militar oficial". De fato, em comparação com a origem dos genros, há uma maior concentração de noras cujas origens são de "filhas de grandes proprietários fundiários”, mas também ocorre, ao contrário do recrutamento dos genros, uma maior dispersão de origens na estrutura social: pode-se observar que
7,27\% delas são "filhas de comerciantes", 3,67\% delas são "filhas de funcionários públicos” e 10,91\% são classificados como tendo origem em outras situações sociais. Se for considerado que esses últimos matrimônios podem ser menos exitosos que os primeiros, então se pode conclui que há um maior controle social sobre os matrimônios realizados pelas mulheres da elite estancieira, quando em comparação com os homens desse estrato social. No caso da origem dos genros, 94,59\% possuem origem ou estancieira e/ou apresentam algum título, militar ou escolar; já no caso da origem das noras, 78,18\% possuem origem como "filhas de estancieiros" e/ou cujos pais apresentam algum título militar ou escolar. Além de representar um maior controle por parte do casamento das mulheres, esses dados são um forte indício de que o matrimônio dos filhos e o das filhas cumprem estratégias diferentes de reprodução familiar - assunto que será tratado mais adiante.

Quanto às estratégias de casamentos endogâmicos às famílias, observa-se sua fraca prevalência, se considerado como grau de parentesco endogâmico os primos de primeiro e segundo graus, pois representam somente 7,07\% dos matrimônios. A "família 3" é a que apresenta o maior número desse tipo de estratégia, com 3 casamentos entre primos de primeiro grau, todos na segunda geração, de um total de 19 casamentos - representando 15,8\%. As demais famílias apresentam apenas um casamento consanguíneo cada, com exceção da "família 4", na qual não se registrou nenhum caso. Nenhum caso fora registrado de casamentos envolvendo outros laços de parentesco, como entre tios e sobrinhas e entre concunhados -homem que adquire como cunhado o irmão da mulher de seu irmão ou o marido da irmã -, do total de 99 matrimônios. Fari- 
natti (2010, p. 280) encontrou casos de 20\% dos matrimônios realizados entre parentes consanguíneos nas famílias da elite estancieira da primeira metade do século XIX. No que se refere ao período por mim analisado, parece haver uma tendência semelhante ao que fora registrado por Lewin (1993) quanto aos casamentos endogâmicos realizados pela elite proprietária de terras da Paraíba. A autora registrou uma queda desse tipo de matrimônio durante a República Velha, quando em comparação à geração anterior que se casara durante o Império, de 35\% para $15 \%$.

Nos dois casos, parece haver um movimento em direção a uma maior abertura quanto aos matrimônios em direção à incorporação na família de indivíduos não-consanguíneos - "talentosos" - que possam não somente manter ou aumentar o patrimônio em terras, mas também equipar a família com outros tipos de capitais, em especial o de relações sociais. 0 casamento endogâmico consolidava a propriedade rural num contexto de herança baseado na partilha, além das redes de poder político estabelecidas e da coesão social do grupo familiar. Contudo, a centralidade dessa estratégia matrimonial perde importância ao longo das décadas pelo deslocamento na organização das redes políticas locais para incorporar eixos de alcance maior e de outros recursos relacionados com o acúmulo de prestígio e relações sociais com os investimentos escolares ou em carreiras militares - situações registradas por Lewin (1993) como tendências de alcance nacional. Uma das primeiras consequências teria sido a erosão do poder da autoridade patriarcal sobre os casamentos, aumentando a confıança nas estratégias exogâmicas, na medida em que a exogamia assume maior importância política.
Um outro fator que ajuda a explicar o alto grau de matrimônios por homologia de posições, no caso em análise, é que não se tratava de uma elite em descenso político ou econômico, pelo menos a partir de 1930. Senão pelo contrário, a constituição de uma rede de frigoríficos, que substituíram as charqueadas, e a Revolução de 1930 ampliaram as possibilidades de acúmulo de capital econômico e de relações sociais, respectivamente (PICCIN, 2014). As pressões, nesse caso, para reconversão/constituição de novas trajetórias não se deram do mesmo modo que no caso da elite dos engenhos de açúcar do Nordeste (GARCIA JUNIOR, 2007). Ali, a incorporação de indivíduos não-consanguíneos "talentosos" à família ampliava a possibilidade da reconversão/constituição de trajetórias para fora do grupo social dos grandes proprietários rurais e/ou o aumento das relações sociais, que poderia municiar seus integrantes com novos capitais a fim de evitar o descenso social. Dito de outro modo, os bacharéis eram títulos importantes não somente para a ampliação da rede de influência, mas para a readequação do volume e estrutura de capitais individuais e familiares em uma economia em crise constante do preço do açúcar. Aqui, diferentemente, o alto grau de homologia nos matrimônios, ou seja, entre descendentes de estancieiros, indica uma centralidade do capital econômico via acúmulo de terras que os cônjuges trazem consigo por ocasião do casamento e/ou das heranças.

Outra informação fundamental são os indícios de que as estratégias matrimoniais constituídas com as filhas e com os filhos cumprem funções diferentes nas famílias. A origem de recrutamento das noras é mais concentrada entre descendentes de estancieiros do que a origem dos genros, de $76,36 \%$ e 59,47\% respectivamente. Ao 
mesmo tempo, o casamento dos homens é consentido com estratos sociais que não aparecem no caso do casamento das mulheres, como "comerciante" 7,27\%, "funcionário público" 3,64\%, e "outro" 10,91\%; no caso das mulheres, somente $5,41 \%$ dos matrimônios ocorrem com a categoria de "outro", e nenhum com as demais. Por outro lado, $18,92 \%$ dos matrimônios das mulheres são realizados com "militares”, assim como 16,22\% deles são realizados com "bacharéis" - no caso dos matrimônios realizados pelos homens, apenas 1,82\% ocorrem com filhas de "militares" e nenhum matrimônio com filhas de "bacharéis". Isso indica que nas estratégias matrimoniais cabia às mulheres a função de ampliar as redes de relações valorizadas da família para fora da categoria de grandes proprietários de terra: bem entendido, com "militares" e com "bacharéis". Desse ponto de vista, dado o alto grau de homologia no matrimônio dos homens, as filhas representavam um trunfo das famílias no acúmulo de capital de relações sociais que, todavia, tendiam a contrabalançar seu fraco capital social em aumento dos domínios fundiários. Do ponto de vista familiar, representa que enquanto às mulheres cabia ampliar o capital de relações sociais sob um estrito controle dos pais, aos homens era a manutenção e ampliação dos ativos fundiários que estavam em jogo, somado a uma possível maior liberdade para a escolha dos cônjuges em outras categorias sociais - não apenas as mais valorizadas -, o que, no entanto, poderia comprometer a ampliação do patrimônio fundiário herdado.

Uma das maiores fontes que expressam o poder simbólico das linhagens acabam sendo os sobrenomes de seus integrantes, que buscam mobilizá-los no estoque de nomes da família de acordo com o potencial de capital social neles incorporado. Assim como observado por Lewin (1993), no caso da Paraíba, neste caso analisado por mim também não há uma regra fixa de nominação, nem corresponde inteiramente ao traçado da descendência; diferentemente da América hispânica, onde existia uma fórmula de nomenclatura mais estabelecida para selecionar bilateralmente os sobrenomes de um indivíduo. Tanto no caso estudado pela autora quanto por este artigo, a atribuição dos sobrenomes demonstra grande flexibilidade. Se há alguma regra possivel de ser encontrada, ela se relaciona com as possibilidades de mobilizar os nomes com maior poder simbólico incorporado, capazes de demonstrar que o indivíduo que os assina compõe uma ampla e importante rede social. Assim, a seleção dos sobrenomes de um indivíduo pode considerar a herança bilateral ou não, ou mesmo de parentes distantes que nem mesmo os pais os utilizavam mais, mas que são importantes pelas relações que expressam, como o de um avô ou bisavô. Mais precisamente, o sistema de estabelecer os nomes da descendência é ambilinear, ou seja, considerado a partir da linhagem de um ou de ambos os pais. Nesse sentido, os nomes funcionam como projeções da honra da(s) família(s) na sociedade e anunciam uma acumulação de virtude e status reconhecidos socialmente.

\section{Herança, matrimônios e propriedade da terra}

Nesta seção, a análise recai sobre o patrimônio em terras que cada cônjuge traz ao matrimônio e às estratégias de sucessão. Se o estilo de vida de elite é determinado pela quantidade de terras, o quanto cada um dos cônjuges herda para formar um novo núcleo familiar é determinante 
de tal situação. Caso contrário, deve haver algum tipo de reconversão exitosa em profissões ou o casamento com detentores de altos postos burocráticos, como no caso de militares, para evitar o descenso social e a desclassificação.

Os dados que seguem abaixo foram obtidos por duas vias, quais sejam, o Cadastro do Incra e por meio de entrevistas de alguns integrantes de cada uma das linhagens. Por vezes, essas duas fontes de pesquisa foram complementares, pois, por exemplo, no cadastro do Incra havia a referência a um único proprietário, mas já havia sido realizada a partilha e permanecido a propriedade em forma de condomínio. Das seis linhagens pesquisadas, apresento dados de quatro delas, pois nem todos os matrimônios das demais linhagens foi possivel colher as informações. Em todas as quatro havia um integrante considerado pelos demais como alguém que mais sabia da genealogia familiar, e foi com essas pessoas que os dados que seguem foram obtidos. Por vezes, eles foram confirmados e/ou corrigidos por meio de outras entrevistas. Em duas das linhagens pesquisadas havia livros genealógicos de posse do integrante entrevistado, o que facilitava falar de seus antepassados. Nas demais, foi impressionante perceber como os entrevistados sabiam de memória toda a linhagem até o seu fundador, as histórias pessoais, os feitos e dramas de cada um, cuja dificuldade residia no próprio pesquisador em entender todas as ligações.

Contudo, assinalo que este é um assunto muito difícil de ser tratado pelos entrevistados, pois, primeiro, é preciso ter confiança em seu interlocutor de que tais dados têm interesse apenas acadêmico e, mais importante, porque, por vezes, rememora mágoas de família ainda não bem resolvidas quando alguém é considerado injustiçado na partilha da herança. Nesse sentido, não era um assunto tratado por mim em todas as entrevistas, mas somente quando o entrevistado se mostrava com disposição e à vontade para falar sobre ele. Foi mais fácil conseguir as informações sobre a primeira geração, em que apresento dados de 18 matrimônios, do que a segunda geração, em que apresento dados de 11 matrimônios. Se em qualquer entrevista, o fato de fazer perguntas, consideradas pelo entrevistado como desagradáveis, pudesse comprometer a continuidade da mesma, neste caso a sutileza das respostas evasivas era convidativa para se trocar de assunto.

Uma outra observação com relação à declaração e ao tratamento dos dados é que, não custa lembrar, não se trata de uma pesquisa documental em matrículas de imóveis, mas baseada nas declarações de informantes-chave. Nas matrículas dos imóveis haveria a cadeia dominial em que o patrimônio foi efetivamente objeto de transações as mais variadas, o que, talvez, desse uma maior exatidão aos dados. Por exemplo, algumas das declarações ao pesquisador sobre o tamanho do patrimônio eram feitas utilizando-se a unidade de medida “quadra de campo", equivalente a 87,12 ha, sendo então transformadas por mim na unidade de medida "hectares". Outra questão importante é que as questões aos entrevistados diziam respeito sobre o quanto cada um dos cônjuges da primeira geração havia trazido para o casamento e de como os integrantes da segunda geração haviam herdado. As propriedades da primeira geração foram efetivamente herdadas pelos descendentes da segunda geração, no período entre 1970 e o final dos anos 1990. Em dois casos, já estava em discussão entre as famílias a divisão da herança do que 
estou chamando de segunda geração. Não importava o que as pessoas fizeram com as propriedades herdadas, se venderam ou se houve a compra de mais terras. Os dados apresentados, a seguir, traduzem apenas o momento da transmissão da herança e a soma das frações herdadas pode não coincidir com aquela dividida originalmente. Os valores apresentados também não são, necessariamente, referentes a apenas um imóvel, podendo ser referente à soma de dois ou mais. Além disso, o total herdado pode não se traduzir em novos estabelecimentos, que continua indiviso, mas cuja propriedade é dividida em porcentagens entre os(as) herdeiros(as). Com o passar dos anos, a propriedade pode até mesmo ser reconcentrada com a venda das parcelas a um(a) dos(as) herdeiros(as), ou, como ocorre mais recentemente, a terceiros.

Feitas essas observações, passamos então à análise propriamente dita entre estratégias de sucessão, matrimônios e propriedade da terra. 0 Quadro 1 apresenta um panorama geral do conjunto dos matrimônios, sendo que os detalhes das estratégias de cada família seguem no Quadro 2. 0 Quadro 1 é relativo à média de hectares de terra herdados pelo conjunto dos(as) filhos(as) na primeira geração e segunda geração. Em seguida, separa essas médias entre os filhos e as filhas e apresenta a média do quanto de hectares as noras e os genros trazem aos matrimônios.

Quadro 1: Médias de hectares de terra herdados e trazidos ao casamento pelos cônjuges

\begin{tabular}{|c|c|c|c|c|c|}
\hline \multicolumn{3}{|l|}{ 1ª Geração } & \multicolumn{3}{|l|}{ 2a Geração } \\
\hline $\begin{array}{l}\mathrm{N}^{0} \text { de } \\
\text { herdeiros(as) }\end{array}$ & $\begin{array}{l}\text { Média ha } \\
\text { herdados dos } \\
\text { pais }\end{array}$ & & $\begin{array}{l}\text { No de } \\
\text { herdeiros(as) }\end{array}$ & $\begin{array}{l}\text { Média ha } \\
\text { herdados dos } \\
\text { pais }\end{array}$ & \\
\hline 18 & 1249 & & 11 & 510 & \\
\hline $\begin{array}{l}\text { Filhos (10) - } \\
\text { média em ha }\end{array}$ & $\begin{array}{l}\text { Noras - média } \\
\text { em ha }\end{array}$ & $\begin{array}{l}\text { Total ha no } \\
\text { matrimônio }\end{array}$ & $\begin{array}{l}\text { Filhos (9) } \\
\text {-média em ha }\end{array}$ & $\begin{array}{l}\text { Noras - média } \\
\text { em ha }\end{array}$ & $\begin{array}{l}\text { Total ha no } \\
\text { matrimônio }\end{array}$ \\
\hline 1381 & 880 & 2261 & 496 & 347 & 843 \\
\hline $\begin{array}{l}\text { Filhas (8) - } \\
\text { média em ha }\end{array}$ & $\begin{array}{l}\text { Genros - média } \\
\text { em ha }\end{array}$ & $\begin{array}{l}\text { Total ha no } \\
\text { matrimônio }\end{array}$ & $\begin{array}{l}\text { Filhas (2) - } \\
\text { média em ha }\end{array}$ & $\begin{array}{l}\text { Genros - média } \\
\text { em ha }\end{array}$ & $\begin{array}{l}\text { Total ha no } \\
\text { matrimônio }\end{array}$ \\
\hline 1153 & 458 & 1610 & 576 & 125 & 701 \\
\hline
\end{tabular}

Fonte: dados próprios - pesquisa de campo

A primeira observação a se fazer é que a média do patrimônio herdado pela primeira geração é mais do que o dobro do que foi herdado pela segunda geração, de 1249 ha e de 510 ha, respectivamente. A mesma tendência se observa no caso do patrimônio formado pelos matrimônios da segunda geração. Enquanto no primeiro caso, a média de hectares herdados pelos filhos é ligeiramente maior que das filhas, o contrário ocorre na segunda geração, o que indica que não há, necessariamente, uma regra que define menores heranças para as mulheres. Um primeiro fator que se concluiu é que o patrimônio formado no matrimônio é fundamentalmente dependente da 
quantidade de terras trazidas pelas noras e genros. No primeiro caso, o patrimônio nos matrimônios dos filhos aumenta em mais de 50\%, e no segundo caso, quase dobra. Já o patrimônio no matrimônio das filhas é acrescido de praticamente 50\% no primeiro caso, e no segundo caso de 20\%. Essa média menor no matrimônio das filhas é coerente com o que foi discutido na seção anterior, uma vez que, em dois casos, o casamento com militares não acresceu em nada nas terras acumuladas, mas em outros tipos de capitais. Já os matrimônios dos filhos foram realizados sobretudo com noras cujos pais eram estancieiros, o que justifica que a média de terras acumuladas aumente em relação às suas irmãs. De todo modo, o Quadro 1 mostra a centralidade que tem os matrimônios na constituição dos patrimônios em terras e, portanto, na manutenção dos estilos de vida de elite. Esses dados são expostos com maiores detalhes no Quadro 2, que traz um outro fator fundamental: o número da prole.

0 Quadro 2 mostra as estratégias sucessorais de acordo com os matrimônios individualmente em cada família. Os filhos e filhas da primeira geração são a prole de um único casal, assim como os filhos e filhas da segunda geração são a prole do casal destacado no Quadro com fundo em cinza. Portanto, trata-se da análise de dois núcleos familiares, um na primeira geração e outro na segunda. Todos os matrimônios desses núcleos familiares foram objetivados no quadro, a seguir. 
Quadro 2. Patrimônio herdado e trazido ao matrimônio pelas noras e genros.

\begin{tabular}{|c|c|c|c|c|c|c|c|}
\hline \multicolumn{4}{|c|}{ Linhagem 1} & & & & \\
\hline \multicolumn{4}{|c|}{ 1ª Geração } & \multicolumn{4}{|c|}{ 2a Geração } \\
\hline Filhos & Herança (ha) & Noras (ha) & Total (ha) & Filhos & Herança (ha) & Noras (ha) & Total (ha) \\
\hline 1 & 800 & 500 & 1300 & 1 & 221 & 0 & 221 \\
\hline 2 & 900 & 1500 & 2400 & 2 & 250 & 214 & 464 \\
\hline 3 & 1002 & 871 & 1873 & 3 & 221 & 1650 & 1871 \\
\hline 4 & 758 & 850 & 1608 & - & - & - & - \\
\hline Média & 865 & 930 & 1795 & Média & 231 & 621 & 852 \\
\hline Filhas & Herança (ha) & Genros (ha) & Total (ha) & Filhas & Herança (ha) & Genros (ha) & Total (ha) \\
\hline 5 & 780 & 1100 & 1880 & 4 & 221 & 0 & 221 \\
\hline 6 & 856 & 0 (militar) & 856 & - & - & - & - \\
\hline 7 & 856 & 250 & 1106 & - & - & - & - \\
\hline Média & 830 & 450 & 1280 & Média & 221 & 0 & 221 \\
\hline \multicolumn{8}{|c|}{ Linhagem 2} \\
\hline \multicolumn{4}{|c|}{ 1ª Geração } & \multicolumn{4}{|c|}{ 2a Geração } \\
\hline Filhos & Herança (ha) & Noras (ha) & Total (ha) & Filhos & Herança (ha) & Noras (ha) & Total (ha) \\
\hline 1 & 1481 & 1133 (prima) & 2614 & 1 & 960 & 110 & 1070 \\
\hline 2 & 1500 & 870 (prima) & 2370 & 2 & 960 & 450 & 1410 \\
\hline 3 & 1481 & 560 (prima) & 2041 & - & - & - & - \\
\hline 4 & 1481 & 450 & 1931 & - & - & - & - \\
\hline Média & 1486 & 1170 & 2239 & Média & 960 & 280 & 1240 \\
\hline \multicolumn{8}{|c|}{ Linhagem 3} \\
\hline \multicolumn{4}{|c|}{ 1ª Geração } & \multicolumn{4}{|c|}{ 2a Geração } \\
\hline Filhos & Herança (ha) & Noras (ha) & Total (ha) & Filhos & Herança (ha) & Noras (ha) & Total (ha) \\
\hline 1 & 1929 & 570 (prima) & 2499 & 1 & 950 & 0 & 950 \\
\hline 2 & 1929 & 1500 & 3429 & - & - & - & - \\
\hline Média & 1929 & 1035 & 2964 & Média & 950 & 0 & 950 \\
\hline Filhas & Herança (ha) & Genros (ha) & Total (ha) & Filhas & Herança (ha) & Genros (ha) & Total (ha) \\
\hline 3 & 1929 & 300 & 2229 & 2 & 930 & 250 & 1180 \\
\hline Média & 1929 & 300 & 2229 & Média & 930 & 250 & 1180 \\
\hline \multicolumn{8}{|c|}{ Linhagem 4} \\
\hline \multicolumn{4}{|c|}{ 1ª Geração } & \multicolumn{4}{|c|}{ 2a Geração } \\
\hline Filhas & Herança (ha) & Genros (ha) & Total (ha) & Filhos & Herança (ha) & Noras (ha) & Total (ha) \\
\hline 1 & 1300 & 400 & 1700 & 1 & 400 & 0 & 400 \\
\hline 2 & 900 & 569 & 1469 & 2 & 150 & 400 & 550 \\
\hline 3 & 1500 & 850 & 2350 & 3 & 350 & 300 & 650 \\
\hline 4 & 1100 & 193 & 1293 & - & - & - & - \\
\hline Média & 1200 & 503 & 1703 & Média & 300 & 233 & 533 \\
\hline
\end{tabular}

Fonte: dados próprios - pesquisa de campo. 
De modo geral, o Quadro 2 detalha a importância da realização de matrimônios exitosos para a manutenção de grandes propriedades, com as particularidades de cada uma das famílias pesquisadas. As heranças não se dão sempre em partes iguais, há modos diferentes de pensar a divisão dos bens da família. Na maior parte desses casos, a porção de terra em que se localiza a sede da propriedade cabe ao filho que teve a função de administrar a estância até a morte dos pais, cuja parcela também pode ser maior que os demais; não encontrei a campo o caso de filhas que assumiram tal função. 0 tamanho da parcela herdada também depende da qualidade da terra; terras com relevo acidentado e/ou afloramento de rochas são consideradas de menor qualidade, o que justifica uma quantidade maior a ser herdada.

É interessante perceber que os patrimônios nos matrimônios 1, 2 e 4 da segunda geração da primeira linhagem apresentada no Quadro 2, respectivamente com 221 ha, 464 ha e 221 ha, foram apresentados pelo meu entrevistado como insuficientes "para se viver”. Ou seja, não são considerados como suficientes para reproduzir os estilos de vida do grupo se não forem acompanhados do acúmulo de outros tipos de capitais. 0 terceiro herdeiro com 221 ha só foi salvo da desclassificação por causa de um casamento exitoso, em que sua esposa herdou 1650 há - um montante de patrimônio que permite reproduzir estilos de vida da elite estancieira apenas com base na propriedade da terra.
A segunda linhagem apresenta a característica particular de haver três matrimônios entre primos na primeira geração. Contudo, o fundamental a se perceber é que, quando se compara com os outros matrimônios realizados na primeira geração das demais linhagens, não é a consanguinidade e a respectiva manutenção do patrimônio da linhagem que definem a existência de grandes propriedades. Ou seja, se a média geral dos demais patrimônios formados em razão dos casamentos fosse sensivelmente menor que aqueles em consanguinidade, então se poderia dizer que essa seria uma estratégia exitosa quando se observa o conjunto dos matrimônios, por mais que possa ter sido no caso particular.

Já os matrimônios das linhagens 3 e 4 só confirmam o que pode ser observado também nas demais, uma vez que as médias dos patrimônios, quando se observa dentro de cada geração, não variam consideravelmente quanto aos fatores que as definem: o número da prole e os matrimônios bem-sucedidos. São essas as duas principais estratégias utilizadas nas famílias, que permitem a existência de um tamanho de propriedade da terra capaz de garantir os estilos de vida da elite estancieira. Um número grande de filhos(as) aumenta a importância de que os matrimônios sejam bem-sucedidos. A relação entre o número de filhos e o total herdado por cada um deles pode ser visto na Tabela 2. 
Tabela 2. Tamanho da propriedade dependente das taxas de fecundidade das famílias.

\begin{tabular}{|c|c|c|c|c|c|}
\hline 1ª Geração & & & 2a Geraçã & & \\
\hline $\begin{array}{l}\text { No de } \\
\text { filhos(as) }\end{array}$ & Total de ha dos pais & Média & $\begin{array}{l}N^{\circ} \text { de } \\
\text { filhos(as) }\end{array}$ & Total de ha herdados & Média \\
\hline 7 & 5951 & 850 & 4 & 913 & 228,25 \\
\hline 4 & 5943 & 1486 & 2 & 1920 & 960 \\
\hline 3 & 5787 & 1929 & 2 & 1880 & 940 \\
\hline 4 & 4800 & 1200 & 3 & 900 & 300 \\
\hline
\end{tabular}

Fonte: dados próprios - pesquisa de campo. Elaborada pelo autor.

Na Tabela 2 pode-se observar que as famílias mais numerosas são as que transmitem menores patrimônios individualmente aos(às) herdeiros(as), o que atesta que as taxas de fecundidade são determinantes para o tamanho da propriedade que se constitui na geração procedente. Além disso, pode-se perceber uma diminuição da taxa de fecundidade entre as gerações, enquanto que a taxa média brasileira aumentava no mesmo período. Se pegarmos as médias das taxas de fecundidade acima, temos 4,5 para a primeira geração, que nasceu entre 1900 e 1930, e 2,75 para a segunda geração, que nasceu entre 1920 e 1960. Já a taxa média de fecundidade para o país em 1940, quando houve o primeiro registro, era de 6,16, sendo de 6,21 em 1950 e de 6,28 em 1960, caindo posteriormente até os dias atuais (IBGE, 2019). Isso indica que a prática de redução da fecundidade se constituiu como uma preocupação anteriormente à média das demais classes sociais.

Outro dado de campo, que não está presente nos quadros e tabelas apresentados, indica, no mesmo sentido, a importância da herança na constituição das grandes propriedades. Me refiro à prática de celibato. Diferentemente dos casos mais clássicos de celibato descritos entre camponeses, que não herdam a propriedade como estratégia de deixá-la o menos indiviso possível, no caso analisado os(as) solteiros(as) herdam igualmente como os(as) que realizam matrimônio. Como não possuem filhos(as) legitimos, transmitem a propriedade aos seus sobrinhos(as) e, desse modo, acabam por garantir a reprodução econômica da segunda geração, o que também reduz a pressão de partilha sobre o patrimônio dos(as) irmãos(ãs) que casaram, pois o(a) sobrinho(a) que herdou não entra na partilha de seus pais. Em quatro dos casos analisados, três em uma mesma linhagem, cada um dos(as) tios(as) transmitiram a totalidade de suas posses a um de seus sobrinhos(as), que também eram seus afilhados. Ou seja, a propriedade passou para a segunda geração sem sofrer processos de partilha.

\section{Considerações finais}

Os espaços de interações sociais e culturais da elite estancieira eram responsáveis pela construção de um habitus de classe reconhecível e comunicável, num primeiro olhar, por seus participantes. Uma verdadeira classe social no sentido sociológico do termo, em que há uma autoidentificação entre seus integrantes como componentes de um mesmo grupo, como pessoas "da sociedade”, como diziam meus entrevistados. Nesses espaços, se expressava a maior de 
todas as distinções sociais que era a distância da necessidade, ou ainda, uma espécie de comemoração/demonstração de que não se precisava trabalhar na terra para se viver; uma distinção assegurada justamente pela posse de grandes extensões de terra cuja exploração se dá com o gado criado de modo extensivo. Essa distinção assegurava a reprodução de um estilo de vida aristocrata dedicado às artes, à literatura, à cultura de um modo geral, aos esportes, à política e à guerra. Nada mais equivocado seria, portanto, atribuir o chamado gauchismo, enquanto rituais de celebração das práticas de trabalho nas estâncias pelos CTG's (Centros de Tradições Gaúchas) à elite estancieira. Esta elite, grande proprietária de terra, buscava o cosmopolitismo e consumia bens culturais universais dos mais distintos, assim como aqueles que se desenvolviam na capital do país. A assimetria em termos de estilos de vida quando comparados com as demais classes e grupos só poderia repercutir em uma forte endogamia de suas estratégias matrimoniais.

A principal conclusão sobre as estratégias matrimoniais é com relação a alta taxa de homologia de posição entre os cônjuges. No caso do recrutamento de noras à família, 76,36\% delas são filhas de estancieiros, enquanto que 59,46\% dos genros possuem essa mesma origem. Todavia, apesar dos casamentos dos homens serem mais concentrados dentro do próprio grupo de grandes proprietários, é menor o controle familiar e há uma maior permissão para que os matrimônios se deem com as filhas de outras categorias sociais, como comerciantes, funcionários públicos e outros. No caso do casamento das mulheres, apesar de ser menos concentrado internamente à sua própria classe social, é maior o controle familiar para que os casamentos, caso não sejam com filhos de estancieiros, se deem restritivamente com militares ou bacharéis. Isso pode ser demonstrado se somarmos aos índices já citados os casos de matrimônios que envolvem as categorias sociais de militares ou bacharéis. No caso da origem dos genros, 94,59\% possuem origem ou estancieira e/ou apresentam algum título, ou militar ou escolar; já no caso da origem das noras, 78,18\% possuem origem como filhas de estancieiros e/ou cujos pais apresentam algum título militar ou escolar.

É possível também concluir que as estratégias matrimoniais das filhas acabam por alargar o capital de relações sociais da família, uma vez que envolvem as categorias de bacharéis e militares, 16,22\% e 18,92\%, respectivamente. Dessa forma, índices muito superiores aos realizados pelos filhos com essas mesmas categorias sociais, de $0 \%$ e $1,32 \%$, respectivamente. Por outro lado, enquanto as estratégias de reprodução das filhas envolvem, portanto, manter estilos de vida de elite também com essas duas categorias sociais citadas, mesmo que ao preço de uma diminuição do patrimônio em terras no matrimônio, uma vez que seus cônjuges não trazem herança em terras por ocasião do casamento, as estratégias de reprodução social exitosas dos filhos precisam garantir um casamento com uma filha de estancieiro para poder aumentar o patrimônio em terras herdado. Especialmente nesse caso, um mau-casamento pode determinar a desclassificação social dele próprio ou de seus descendentes, uma vez que a herança pode ser pequena para se manter os estilos de vida esperados.

As estratégias endogâmicas às linhagens possuem uma fraca prevalência, de apenas 7,07\% dos matrimônios. Considerando que é alta a taxa das estratégias matrimoniais por homologia de posição, isso indica que os meios de interação social e cultural 
cumpriam um papel central na socialização para o reforço dos habitus de elite e, consequentemente, para a constituição de afınidades eletivas em que a homologia do matrimônio ganhava a força de liberdade para os cônjuges - era tomado como natural e fruto das opções individuais constituir matrimônio com seus pares também socializados em um mesmo ambiente social.

Quanto às estratégias sucessorais, um primeiro fator que se concluiu é que o patrimônio formado no matrimônio é fundamentalmente dependente da quantidade de terras trazidas pelas noras e genros. A média do patrimônio herdado pela primeira geração é mais do que o dobro do que foi herdado pela segunda geração, de 1249 ha e de 510 ha, respectivamente. 0 tamanho do patrimônio do grupo familiar é dependente da realização de um bom matrimônio. Caso contrário, se a propriedade for fracionada em porções menores que 500 ha, por ocasião da herança, é a reprodução dos estilos de vida de elite que ficam comprometidos.

0 outro fator fundamental na determinação do tamanho do patrimônio a ser herdado é a taxa de fecundidade. Quanto maior for o número de filhos(as), a reprodução dos estilos de vida depende cada vez mais da realização de bons matrimônios. São essas as duas principais estratégias utilizadas nas famílias que permitem a existência de um tamanho de propriedade da terra capaz de garantir os estilos de vida da elite estancieira.

As estratégias de matrimônios endógenos à linhagem não se destacam na quantidade de terra formada por ocasião do matrimônio, ou quando da herança. Isso indica que as estratégias de casamentos consanguíneos seguiam outro princípio que não guiadas pelo capital econômico, mas, talvez, pelo poder simbólico da própria linhagem.

\section{Referências}

ALVES, A. C. A produção antroponômica para a política: casos no Paraná, Brasil. Brasília (DF). In: CONGRESSO BRASILEIRO DE SOCIOLOGIA, 18 GT 33: Família, Instituições e Poder, 2017, Brasília. Anais... Brasília, 26 a 29 de julho de 2017.

Redes familiares: estratégias matrimoniais e clientelares de uma elite em ascensão (Guarapiranga - século XVIII). Dimensões, v. 39, jul.-dez., p. 220-243, 2017.

BONNAIN, R.; BOUCHARD, G.; GOY, J. (Orgs.). Transmettre, hériter, succéder: la reproduction sociale en milieu rural France-Québec XVIIIe-XXe siècles. Lyon: PUL, 1992.

BOURDIEU, P. Le sens pratique. Paris: Minuit, 1980.

La Noblesse d'état. Grandes écoles et esprit de corps. Paris: les editions de minuit, 1989.

0 Poder Simbólico. 6. ed. Rio de Janeiro: Bertrand Brasil, 2002a.

Le bal des célibataires. La crise de la société paysanne en Béarn. Paris: Seuil, 2002b.

A distinção: crítica social do julgamento. São Paulo: Edusp; Porto Alegre: Zouk, 2008.

SAINT MARTIN, M. Le Patronat. Actes de la Recherche en Sciences Sociales. v. 20-21, mars/ avril, p. 3-82, 1978.

BRUNO, R. Movimento "Sou Agro": marketing, habitus e estratégias de poder do agronegócio. Composição: Revista de Ciências Sociais, v. 14, p. 85-101, 2014.

BÜHLER, E. A.; GUIBERT, M.; OLIVEIRA, V. L. Agriculturas empresariais e espaços rurais na globalização: abordagens a partir da América do Sul. Porto Alegre: Ed. da UFRGS, 2016.

CAMARG0, 0. J. R. Elite política brasileira e a renegociação das dívidas do crédito rural: o caso da bancada ruralista. 147 f. Dissertação (Mestrado em Sociologia) - Programa de Pós-Graduação em Sociologia da Universidade Estadual de Campinas-Unicamp, Campinas, 2009. 
CANEDO, L. Herança na politica ou como adquirir disposições e competências necessárias às funções de representação política (1945-1964). Pro-posições, v.13, n. 3(39), p. 169-198, set/dez, 2002.

COSTA, F. F. Ação política e representação de interesses do patronato rural gaúcho: uma análise da federação da agricultura do estado do Rio Grande do Sul (1988-2000). 172 f. Dissertação (Mestrado em Ciências Sociais) - Programa de Pós-Graduação em Ciências Sociais, Desenvolvimento Agricultura e Sociedade da Universidade Federal do Rio de Janeiro- UFRRJ. Rio de Janeiro. 2019.

DA ROS, C. Terra e poder no Rio Grande do Sul: as politicas agrárias durante o governo Olívio Dutra (1999-2002). Rio de Janeiro: Garamond, 2012.

DENORD, F.; LAGNEAU-YMONET, P. Le concert des puissants. Paris: Raisons d'agir, 2016.

FARINATTI, L. A. E. Confins Meridionais: famílias de elite e sociedade agrária na fronteira sul do Brasil. Santa Maria: Ed. da UFSM, 2010.

FREYRE, G. Casa-Grande e Senzala. 25. ed. Rio de Janeiro: José Olympio, 1987.

GARCIA JUNIOR, A. O Sul: caminho do roçado, estratégias de reprodução camponesa e transformação social. São Paulo: Marco Zero; Brasília: UnB; MTC-CNPq, 1989.

Os vice-reis do Norte: reconversão de elites agrárias e a Revolução de 1930 (1920-1964). Revista Ciências Sociais, Universidade Federal do Ceará-UFC, 2 (28), p. 73-87, 2007.

GOODY, J. L'évolution de la famille et du mariage en europe. Paris: Armand Colin, 1985.

GRIJÓ, L. A. Origens sociais, estratégias de ascensão e recursos dos componentes da chamada “geração de 1907”. 250 f. Dissertação (Mestrado em Ciência Política) - Programa de Pós Graduação em Ciência Política, Universidade Federal do Rio Grande do Sul-UFRGS, Porto Alegre, 1998.

GRILL, I. G. Parentesco, redes e partidos: as bases das heranças políticas no Rio Grande do Sul. Tese (Doutorado em Ciência Política) - Instituto de Filo- sofia e Ciências Humanas da Universidade Federal do Rio Grande do Sul-UFRGS. Porto Alegre, 2003. HEINZ, F. M. Les fazendeiros a l'heure syndicale: representation professionnelle, interets agraires et politique au Brésil, 1954-1967. Thèse (Doctorat d'Histoire). Nanterre, Université de Paris X, 1996.

HEREDIA, B.; PALMEIRA, M.; LEITE, S. P. Sociedade e economia do "agronegócio" no Brasil. Revista Brasileira de Ciências Sociais, 25, 74, p. 159-196, 2010.

LEWIN, L. Política e parentela na Paraíba: um estudo de caso da oligarquia de base familiar. Rio de Janeiro: Record, 1993.

MARTINS, M. F. Família, estratégias e redes de poder em Minas Gerais (séc. xviii/xix). Acervo, Rio de Janeiro, v. 30, n. 1, p. 121-139, jan./jun. 2017. MARX, K. 018 Brumário de Luís Bonaparte. São Paulo: Boitempo, 2011.

MEDEIROS, L. T. 0 peão de estância: um tipo de trabalhador rural. Porto Alegre, Instituto de Estudos e Pesquisas Econômicas/UFRGS - Estudos e Trabalhos mimeografados $n^{\circ} 8,1969$.

MONTEIRO, J. M.; FERREIRA, R. de F. A Reprodução das Famílias Políticas e as Dimensões da Hereditariedade no Estado da Paraíba. Brasília (DF). $18^{\circ}$ Congresso Brasileiro de Sociologia, Grupo de Trabalho 33: Família, Instituições e Poder, 26 a 29 de julho de 2017.

MOORE JUNIOR, B. As origens sociais da ditadura e da democracia: senhores e camponeses na construção do mundo moderno. São Paulo: Martins Fontes, 1983.

O IMPARCIAL, Jornal. Edições 18 e 31 de outubro de 1936 e Edições de 1940.

OFFERLÉ, M. Sociologie des Organisations Patronales. Paris: La Découverte, 2009.

PEDROZA, M. Estratégias de reprodução social de famílias senhoriais cariocas e minhotas (17501850). Análise Social. Lisboa, n. 194, p. 141163, 2010. 
PICCIN, M. B. Os Senhores da Terra e da Guerra no Rio Grande do Sul: um estudo sobre as estratégias de reprodução social do patronato rural estancieiro. 458 f. Tese (Doutorado em Ciências Sociais). Instituto de Filosofia e Ciências Humanas da Universidade Estadual de Campinas-Unicamp, Campinas, 2012.

Patronato estancieiro gaúcho: de subsidiários das lavouras de exportação a produtores de artigos de luxo. Estudos Sociedade e Agricultura, vol. 22, n. 2, p. 253-285, 2014.

- Acesso a posições de poder pela elite estancieira gaúcha: trajetórias sociais e investimentos escolares. Tempo Social, v. 27, n. 2, p. 305328, 2015.

PIMENTEL, F. Aspectos gerais de São Gabriel. Porto Alegre: Tipografia Gundlach, 1941.

PINÇON, M.; PINÇON-CHARLOT, M. Grandes fortunes: dynastie familiales et formes de richesse em France. Paris: Petite Bibliothèque Payot, 2006.

Sociologie de la Bourgeoisie. Paris : La Découverte, 2007.

Social Power and Power Over Space: How the Bourgeoisie Reproduces itself in the City. International Journal of Urban and Regional Research, v. 42, n. 1, p. 115-125, 2018.

PREFEITURA MUNICIPAL DE SÃO GABRIEL. Florilégio de poetas e proseadores de São Gabriel: “Athenas Riograndese”. Porto Alegre: Pão dos Pobres, 1959.

RAMOS, P. Financiamentos subsidiados e dividas de usineiros no brasil: uma história secular e ... atual? História Econômica \& História de Empresas, XIV. 2, p. 7-32, 2011.

SANTOS, P. S. S. Famílias e agrupamentos: sobre seus domínios e diversificações. Brasília (DF). CONGRESSO BRASILEIRO DE SOCIOLOGIA, $18^{\circ}$, GT 33: Família, Instituições e Poder, 2017, Brasília, Anais... Brasília, 26 a 29 de julho de 2017.

SAUER, S; LEITE, S. P. Expansão agrícola, preços e apropriação de terra por estrangeiros no Brasil. RESR, Piracicaba-SP, v. 50, n. 3, p. 503-524, 2012.
SEIDL, E. A espada como "vocação": padrões de recrutamento e de seleção das elites do exército no Rio Grande do Sul (1850-1930). Dissertação (Mestrado em Ciência Política) - Programa de Pós-Graduação em Ciência Política. Universidade Federal do Rio Grande do Sul-UFRGS, Porto Alegre, 1999.

SILVA, A. V. C. São Gabriel na História: o drama da fronteira. Porto Alegre: Gráfica Editora CITAL, 1963.

STEINER, P. A sociologia econômica. São Paulo: Atlas, 2006.

STOLCKE, V. Cafeicultura: homens, mulheres e capital (1850-1980). São Paulo: Brasiliense, 1986.

SWEDBERG, R. Sociologia econômica: hoje e amanhã. Tempo Social. v. 16, n. 2, p. 7-34, 2004.

VIRET, J. L. La réproduction familiale et sociale en France sous l'Ancien Régime: le rapport au droit et aux valeurs. Histoire et sociétés rurales, 29, p. 165-188, 2008.

ZALIO, P. P. Territoires et activités économiques: une approche par la sociologie des entrepreneurs. Genèses, n. 56, p. 4-27, 2004. 


\section{RESUMO}

Este artigo analisa os principais meios de interação social e cultural e as estratégias matrimoniais e sucessorais de reprodução social da elite grande proprietária de terra criadora de gado extensivo no Rio Grande do Sul. Os meios de interação social e cultural, como clubes, associações culturais e esportivas são fundamentais para a reprodução de um habitus de elite e a constituição de estratégias matrimoniais marcadamente endogâmicas ao próprio grupo. A análise das estratégias sucessorais indica que o tamanho do patrimônio em terras herdado é diretamente dependente da taxa de fecundidade das famílias, assim como o patrimônio formado por ocasião do matrimônio é dependente da realização de um bom casamento. 0 foco da análise são duas gerações que nasceram no século XX, a primeira entre os anos de 1900 e 1930 e a segunda entre 1920 a 1960, em que seis linhagens de grandes proprietários são analisadas, perfazendo 99 matrimônios.

\section{PALAVRAS-CHAVE}

Patronato rural. Elites. Estancieiros. Estratégias matrimoniais. Estratégias sucessorais. Reprodução social.

\section{SUMMARY}

This article analyzes the main means of social and cultural interaction and the marital and succession strategies of social reproduction of the elite which largely owns extensive-cattle-breeding land in Rio Grande do Sul. The social and cultural means of interaction, such as clubs or cultural and sportive associations are fundamental for the reproduction of an elite habitus and the constitution of marital strategies markedly endogamous to the group itself. The analysis of succession strategies indicates that the size of inherited land assets is directly dependent on the fertility rate of the families, as well as that the wealth formed on the occasion of the marriage is dependent on the accomplishment of a good marriage. The focus of the analysis are two generations that were born in the twentieth century, the first between the years of 1900 and 1930, and the second between 1920 to 1960, in which six lines of large proprietors are analyzed, making 99 marriages in total.

\section{KEYWORDS}

Rural patronage. Elites. Farmers. Marital strategies. Succession strategies. Social reproduction. 
